\title{
Physics Teaching in Croatian Elementary and High Schools during the Covid-19 Pandemic
}

IVANA ŠTibi ${ }^{* 1}$, MoJCA ČEPIČ² ANd JeRneJA PAVlin ${ }^{2}$

$\approx$ In spring 2020, 916 elementary schools and 443 high schools were closed in Croatia due to the Covid-19 pandemic and remote teaching was introduced. This had an impact on physics teaching as an experimental subject. In addition to positive aspects concealed in new experiences and work perspectives, the sudden transition from conventional faceto-face teaching to a remote format had an undeniable negative impact on physics teaching in elementary and high schools. In order to mitigate the effects and provide a detailed insight into the problems that arose during this transition, we conducted a quantitative study among teachers of physics in elementary and high schools in Croatia, with the aim of identifying logistical and technical problems and challenges in physics teaching during the Covid-19 pandemic. An online questionnaire with five parts (general data, teaching physics during the Covid-19 pandemic, experiments, sociological component, exchange of experience) was completed by 178 Croatian teachers. The results irrefutably point to the flexibility and responsiveness of physics teachers, an increase in the teachers' workload, a lack of the experimental work that forms an essential part of the subject of physics, and a lack of teacher knowledge (in ICT), skills and equipment for conducting distance teaching. However, it also emerged that online teaching, if carefully designed and individualised, can stimulate additional commitment and interest in the subject among students. The paper presents the research findings in detail, with the aim of helping physics teachers to plan further teaching more effectively as and if the pandemic progresses.

Keywords: Covid-19, distance teaching, experiments, physics, teachers' views

$1{ }^{\star}$ Corresponding Author. Department of Physics, University Josip Juraj Strossmayer, Croatia; istibi@fizika.unios.hr.

2 Faculty of Education, University of Ljubljana, Slovenia. 


\section{Poučevanje fizike v hrvaških osnovnih in srednjih šolah med pandemijo covida-19}

Ivana Štibi, MoJca ČEpič in Jerneja PAVlin

$\approx$ Spomladi 2020 je bilo na Hrvaškem zaradi pandemije covida-19 zaprtih 916 osnovnih šol in 443 srednjih šol ter uvedeno poučevanje na daljavo. To je vplivalo na poučevanje fizike kot eksperimentalnega predmeta. Poleg pozitivnih vidikov, prikritih v novih izkušnjah in delovnih izzivih, je imel nenadni prehod od običajnega pouka $\mathrm{v}$ živo $\mathrm{k}$ pouku na daljavo nesporno negativen vpliv na pouk fizike v osnovnih in srednjih šolah. Da bi prikazali učinke in ponudili podroben vpogled v težave, ki so se pojavile med tem prehodom, smo izvedli kvantitativno raziskavo med učitelji fizike v osnovnih in srednjih šolah na Hrvaškem z namenom prepoznati logistične in tehnične težave ter izzive pri poučevanju fizike med pandemijo covida-19. Spletni anketni vprašalnik s petimi deli (splošni podatki, poučevanje fizike med pandemijo covida-19, eksperimenti, sociološki vidik, izmenjava izkušenj) je izpolnilo 178 hrvaških učiteljev. Rezultati kažejo na prilagodljivost in odzivnost učiteljev fizike, povečanje obremenitve učiteljev, zmanjšanje količine eksperimentalnega dela, ki je bistveni del predmeta fizika, ter pomanjkanje učiteljevega znanja, spretnosti in opreme za izvajanje pouka na daljavo. Izkazalo se je tudi, da lahko pouk na daljavo, če je skrbno zasnovan in individualiziran, spodbudi zanimanje za predmet fizika pri učečih se. Prispevek predstavlja izsledke raziskave $\mathrm{z}$ namenom učiteljem fizike pomagati načrtovati pouk učinkoviteje, če se bo pandemija nadaljevala.

Ključne besede: covid-19, eksperimenti, fizika, pogledi učiteljev, poučevanje na daljavo 


\section{Introduction}

Subsequent to Covid-19 entering Europe, all schools in Croatia - 916 elementary schools and 443 high schools (Ministry of Science and Education, 2021) - were closed on 16 March 2020 , and after a three-day preparation period, the transition to online remote teaching took place. In addition to positive aspects concealed in new experiences and work perspectives (Schröder-Turk \& Kane, 2020), this sudden transition from conventional face-to-face teaching to a remote format had an undeniable negative impact on physics teaching, as an experimental subject, at different educational levels (Union, 2020).

The situation of global long-term distance learning does not occur often, and the increased interest of the educational research community is evident. Due to social distancing and the inability to teach face-to-face, teachers transferred their teaching materials to a digital format and converted their teaching methods to remote methods. Moreover, they chose between synchronous and asynchronous teaching. This choice depends on many factors, from sociological to individual (Union, 2020). Although students adapted to remote teaching methods with varying degrees of difficulty (Azlan et al., 2020), the synchronous part of teaching is ultimately more beneficial to students (Guo, 2020), and the face-to-face method is preferred even if ICT is integrated (Azlan et al., 2020, Sindiani, 2020). Furthermore, in the case of physics teaching as an experimental subject (Klein, et al., 2021), discussing problems and designing one's own experiments and/or conducting experiments (collecting one's own data) individually or in groups should be used to the same extent as demonstration experiments in order to increase students' interest and the perceived usefulness (Kireš, 2018; Repnik \& Ambrožič, 2018; Snětinová et al., 2018). However, frequently used experiments are often "cookbook-type experiments" that are focused on content knowledge instead of focusing on the learning process, mainly due to the organisational aspect (Haagen-Schützenhöfer \& Joham, 2018). In order to avoid this, the authors suggest that teachers undergo professional development (both in ICT and teaching methods) on a regular basis, even in this unusual situation (Walan \& Chang Rundgren, 2014).

In order to fully understand the context of the presented research, the organisation of the Croatian education system, which is centrally managed by the Ministry of Science, Education and Sports (MSES), is presented in Table 1. The Croatian education system provides educational services at preschool, elementary school, high school and higher education levels, and is open and available to all on equal terms according to their abilities. In the present article, lecturers who teach physics are called teachers, and learners of physics at all levels are called students. Elementary school is used when referring to seventh- and eighth-grade 
physics in the lower secondary level of compulsory school. High school is used to refer to various programmes at the upper secondary level.

\section{Table 1}

The Croatian education system

\begin{tabular}{ll}
\hline Preschool education & Preschool education is carried out through programmes of care, educa- \\
& tion, health care, meals and social care for children from 6 months to \\
& school age children, divided into three cycles: (1) from 6 months to one \\
& year of age, (2) from 1 to 3 years of age, (3) from 3 years of age to the \\
beginning of primary school.
\end{tabular}

\begin{tabular}{|c|c|}
\hline Elementary education & $\begin{array}{l}\text { Elementary education includes primary and lower secondary education, } \\
\text { organised as a single structural system beginning at age } 6 \text { and consisting } \\
\text { of eight years of compulsory schooling, delivered through the network of } \\
\text { "elementary" schools. }\end{array}$ \\
\hline $\begin{array}{l}\text { Upper secondary } \\
\text { (high school) } \\
\text { education }\end{array}$ & $\begin{array}{l}\text { Upper secondary (high school) education is not compulsory, but almost } \\
\text { all students enrol in upper secondary general education or vocational pro- } \\
\text { grammes (allowing students to acquire knowledge and skills for work and } \\
\text { for the continuation of education). These programmes are offered by the } \\
\text { network of "middle schools". } \\
\text { - Grammar schools (4-year general education programme): completed } \\
\text { by the state Matura examination; } \\
\text { - Vocational schools (4-5-year vocational education programmes or } \\
\text { 3-year vocational education programmes): completed when the final } \\
\text { paper is prepared, submitted and defended in a process organised and } \\
\text { conducted by the school (duration at least } 4 \text { years) or } \\
\text { - Art schools: completion conditions as for vocational schools. } \\
\text { If a student of art or vocational education programmes lasting at least } 4 \\
\text { years wishes to continue his/her education at a higher education institu- } \\
\text { tion, he/she is required to take the state Matura examination. }\end{array}$ \\
\hline Higher education & $\begin{array}{l}\text { Higher education is divided into two parts and consists of: } \\
\text { - University study programmes, which prepare students for academic or } \\
\text { professional careers in the public and private sectors; } \\
\text { - Professional study programmes, which provide students with an ap- } \\
\text { propriate level of knowledge and skills to enable them to work profes- } \\
\text { sionally and be directly involved in the work process. }\end{array}$ \\
\hline
\end{tabular}

Note. Adapted from Eurydice, 2021.

In order to better understand and interpret the research findings, we also need to look at the recommendations that teachers received from the MSES, as well as their timeline. Official MSES documents first published on 11 March 2020 provide guidelines for primary and secondary schools regarding the establishment of distance education, stating that virtual classrooms should be established by 16 March 2020 involving all students of a given grade along with subject teachers, while parents of students in lower grades should also be involved in the virtual classroom (Ministry of Science and Education, 2020, 11 March). The next document is dated 13 March 2020 and states that on 16 March 2020, "School on the Third Channel" should launch and the virtual classrooms set up should be functioning. 
The recommendations also address the work of teachers and the school, as well as the care of students who cannot stay at home (Ministry of Science and Education, 2020, 13 March). In an amendment to the previous decision of 19 March 2020, the section concerning the teacher's work is changed, stating that s/he should work from home and should be provided with all of the necessary infrastructure for distance education (Ministry of Science and Education, 2020, 19 March). The last of these key documents is the distance education assessment guidelines, which state, among other things, that formative, not summative, assessment is preferred, and that teaching should not be done in real time via video conferencing due to network and system overload (Ministry of Science and Education, 2020, April).

In order to mitigate the negative impact and provide a detailed insight into the problems that arose during the transition from face-to-face to remote teaching, a quantitative study was conducted among physics at elementary and high schools in Croatia. Its aim was to identify logistical and technical problems and challenges in physics teaching during the first cycle of the Covid-19 pandemic (spring 2020).

\section{Research problem and research questions}

In the short time of the Covid-19 pandemic in the spring of 2020, teachers had to transform their "in paper" and "in vivo" teaching materials into remotely applicable materials that similarly motivate, encourage and sustain student interest long enough for them to construct new knowledge (Kluge, 2014; Sullivan et al. 2017).

This adaptation is time-consuming for most teachers, as only a small proportion of them have prior experience in using ICT in some way (Kluge, 2014). In addition to the transfer of materials (digitalisation), there is also the problem of preparing a "Plan B" for unexpected problems such as the overload of educational platforms. It takes time to divide the teaching materials into smaller parts to ensure a clear structure of knowledge and to maintain students' concentration, as well as to appropriately moderate students' homework and reading requirements, while also organising discussion sections after self-learning so that students can share their understanding of the materials (Bao, 2020). In some countries (including Croatia), educational broadcasting is used to support remote teaching (especially for those who do not have internet access) or simply to align teaching methods and materials across the country (Union, 2020).

Among the many problems facing the educational process during the Covid-19 pandemic, we focus particularly on the impact of lockdown on physics education, as physics is an experimental subject that could be affected in additional ways, or affected differently, compared to other subjects. Since the problem is so broad, six research questions focusing on physics teaching were posed in 
order to explore the impact of prolonged absence from school and alternative ways of teaching physics/conducting experiments and assessing knowledge.

- $\quad$ RQ1: How has Covid-19 affected physics lessons?

- $\quad$ RQ2: Which topics were taught and how extensively were they taught?

- $\quad$ RQ3: How was experimental work carried out during remote lessons?

- RQ4: How did Covid-19 affect assessment of students' physics knowledge?

- RQ5: How did teachers perceive the workload during the remote teaching period?

- RQ6: How was communication with students carried out during and alongside physics lessons?

\section{Method}

Research related to physics in the Covid-19 era in Croatia was developed in spring 2020. The study used a descriptive pedagogical research method and a quantitative research approach, taking into account all of the advantages and disadvantages of certain methods in physics education research (Hodson, 2014; Milas, 2005).

\section{Sample}

During May and June 2020, an online questionnaire was completed by 178 Croatian physics teachers ( $71 \%$ female and $29 \%$ male) from all over the country. Participation in the survey was anonymous and voluntary. The age structure of the physics teachers as a whole and divided by school level is presented in Table 2. It can be seen that the majority of the physics teachers are between 30 and 50 years old. The length of service of the physics teachers is shown in Table 3, where it is evident that about $60 \%$ have from 10 to 30 years of experience in education.

\section{Table 2}

Age structure of the physics teachers

\begin{tabular}{lcccccc}
\hline \multirow{2}{*}{ Years } & \multicolumn{2}{c}{$\begin{array}{c}\text { In general } \\
\mathbf{( N = 1 7 8 )}\end{array}$} & \multicolumn{2}{c}{$\begin{array}{c}\text { Elementary } \\
\text { school }\end{array}$} & \multicolumn{2}{c}{ High school } \\
\cline { 2 - 7 } & $\mathrm{n}$ & $\%$ & $\mathrm{n}$ & $\%$ & $\mathrm{n}$ & $\%$ \\
\hline Less than 30 & 15 & 8 & 10 & 8 & 6 & 11 \\
$30-40$ & 68 & 38 & 52 & 41 & 20 & 35 \\
$40-50$ & 53 & 30 & 38 & 30 & 16 & 28 \\
$50-60$ & 32 & 18 & 21 & 16 & 12 & 21 \\
60 and more & 10 & 6 & 7 & 5 & 3 & 5 \\
\hline
\end{tabular}

Note. $\mathrm{N}_{\text {elementary school }}=128, \mathrm{~N}_{\text {high school }}=57.7$ teachers work in elementary and high school. Alongside the number, the corresponding percentage of the participants is given. 


\section{Table 3}

Length of service of the 178 physics teachers

\begin{tabular}{lcccc}
\hline \multirow{2}{*}{ Years } & \multicolumn{2}{c}{ In general } & \multicolumn{2}{c}{ In school } \\
\cline { 2 - 5 } & $\mathrm{n}$ & $\%$ & $\mathrm{n}$ & $\%$ \\
\hline Less than 5 & 17 & 9.61 & 22 & 12.57 \\
$5-10$ & 30 & 16.95 & 32 & 18.29 \\
$10-20$ & 69 & 38.98 & 65 & 37.14 \\
$20-30$ & 41 & 23.16 & 38 & 21.17 \\
30 and more & 20 & 11.30 & 18 & 10.29 \\
\hline
\end{tabular}

Note. Not all of the teachers answered all of the questions. Alongside the number, the corresponding percentage of the participants is given.

Almost $65 \%$ of the teachers who completed the questionnaire work in elementary schools, while the others are from high schools. Only seven respondents declared that they work in both educational levels (elementary and high school) at the same time. The questionnaire reached teachers from all over Croatia, $51 \%$ of whom were from urban schools (Figure 1). Fifty teachers did not answer this question.

\section{Figure 1}

Number of teachers per school stratum

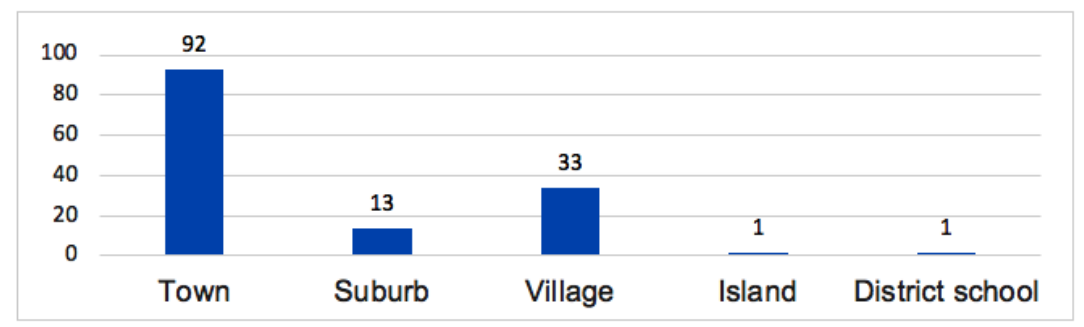

Note. 140 physics teachers answered this question.

Most Croatian universities preparing students to become physics teachers have double-subject study programmes: students can take a combination of physics and mathematics, physics and technical education or physics and comutational science. This allows teachers to fulfil the required workload ( 24 school hours per week) despite having only two school hours of physics per class per week (Constitutional Court of the Republic of Croatia; Ministry of Science, Education and Sport, 2006, 2014). Nevertheless, most teachers who 
answered the questionnaire teach only physics (44\%). Many teach physics and mathematics (27\%), and some teach computer science, technical science or other science subjects (e.g., chemistry) in addition to physics. Details of the distribution of subjects taught are shown in Figure 2.

\section{Figure 2}

Subjects taught by the surveyed teachers during the Covid-19 pandemic
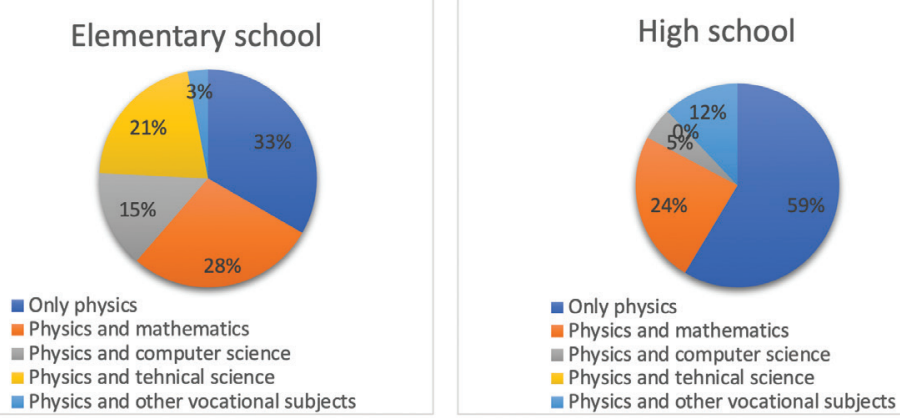

Note. $\mathrm{N}$ $=128, \mathrm{~N}_{\mathrm{h}}$ $=57$ ( 7 teachers work in elementary and high school). Reflects the

percentage of participants answering the question in a certain way.

\section{Instrument}

The data were collected using an online questionnaire for physics teachers. In order to develop the online questionnaire, a qualitative study was conducted as the first part of the research, based on semi-structured interviews with five teachers from elementary schools and five teachers from high schools (conventional sampling) (Bornstein et al., 2017), with the aim of gaining insight into the problems and the situation imposed on them so suddenly by the lockdown. The interviews were conducted via mobile phones or video conferencing due to the epidemiological conditions that prevailed at the time.

After the interviews, the questions and problems relevant to the quantitative part were selected and the questionnaire was developed. Data collection was done by means of an online questionnaire consisting of five parts: general data, physics teaching during the Covid-19 pandemic, experiments before and during the Covid-19 pandemic, sociological component, exchange of experiences. The questionnaire has a total of 33 questions, 8 of which are open-ended questions related to the respondents' own experience during distance teaching of physics, the reactions of students and parents to the methods of distance education, and what the respondents will implement in the future from this part of the teaching experience. The instrument used descriptive categories and corresponding Likert scales. For the purpose of this paper, not all of the questions were evaluated (four were left for further analysis). 


\section{Data analysis}

During the processing of the data, anonymity of the data was ensured for research purposes. After data collection, the teachers' responses were coded and transferred to the SPSS program to perform only basic descriptive statistical analysis at this point. The parametric t-test was used to explain the difference in the quantity of experiments before and during lockdown and not the relationship. The statistical hypothesis was tested with an alpha error rate of $5 \%$.

\section{Results and discussion}

The results and discussions are presented according to the research questions.

- $\quad$ RQ1: How has Covid-19 affected physics lessons?

Given that teachers' ICT knowledge was essential for remote teaching, we investigated the physics teachers' self-assessment of their ICT use. Most of the teachers are very comfortable and confident using all of the ICT needed during online teaching (Figure 3). This is important because the appropriate use of ICT helps to extend and improve the quality of teaching methods and helps to make learning an interesting, active and realistic process for students (Tinio, 2003). The results are similar irrespective of the teachers' school level, elementary or high school. However, social networking sites, such as Facebook, Instagram and the like, are not very popular among the respondents, and they are not very confident in using all of the features they offer.

\section{Figure 3}

Physics teachers' self-assessment of their level ICT use

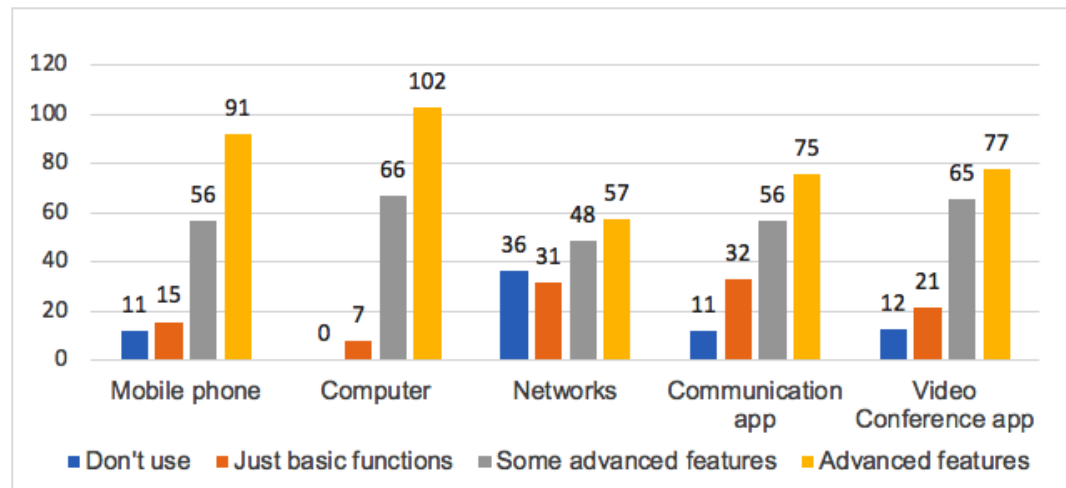


When the lockdown began, the teachers were mostly on their own and had to consider the schedule of their classes taking into account other teachers/subjects and the obligations of their students. Nevertheless, most of them (almost 76\%) retained the same schedule of lessons. Others (15\%) had lessons at different schedule times (in agreement with the students), while $9 \%$ of the teachers had no direct distance teaching.

Apart from having to consider the obligations of the students, there was also a problem of an economic nature. The teachers reported that not all of the students they taught had their own computer or tablet, so they could not follow direct teaching. For example, a simultaneous study with students (our preliminary result), which is not otherwise the subject of this article, shows that 50\% of the students shared a computer or tablet with parents or siblings. Teachers also reported that many students did not have adequate internet access. In addition, not all students were able to use the applications selected by the teachers for direct teaching or knew how to use them. All of this represented an additional burden on the teachers' time: they first had to learn how to use the applications themselves, and then had to demonstrate the applications and teach the students, as expressed in the answers to the open questions. A total of $45 \%$ of the teachers required students to be present during direct remote teaching: from the questionnaire, the elementary and high school data show that $44 \%$ of elementary school physics teachers and $53 \%$ of high school physics teachers required students to be present in class.

The previous school year was quite unusual for the Croatian school system. Apart from the Covid-19 pandemic and online teaching during the second semester, there was a long-lasting strike involving the whole school system during the first semester, which resulted in not all teachers following the curriculum at the same pace. When the lockdown began, the topics that teachers were teaching were therefore quite scattered. This problem is evident for the last few subjects of the first semester (Ministry of Science, Education and Sport, 2019).

\section{Regularity and students' obligations}

The surveyed teachers also reported on student participation and obligations during online classes. A total of $50 \%$ of the teachers did not require students to participate in direct teaching for various reasons, some of which are mentioned above. This was also related to the times when students should either participate or connect to other courses with applications, and to whether students had a computer/tablet/laptop available. Although direct teaching was not compulsory, all other kinds of communication and obligations were 
obligatory. Figure 4 shows the same situation for elementary and high school, so the results are general for all participants.

\section{Figure 4}

Students' obligations during online physics classes, as reported by the surveyed physics teachers
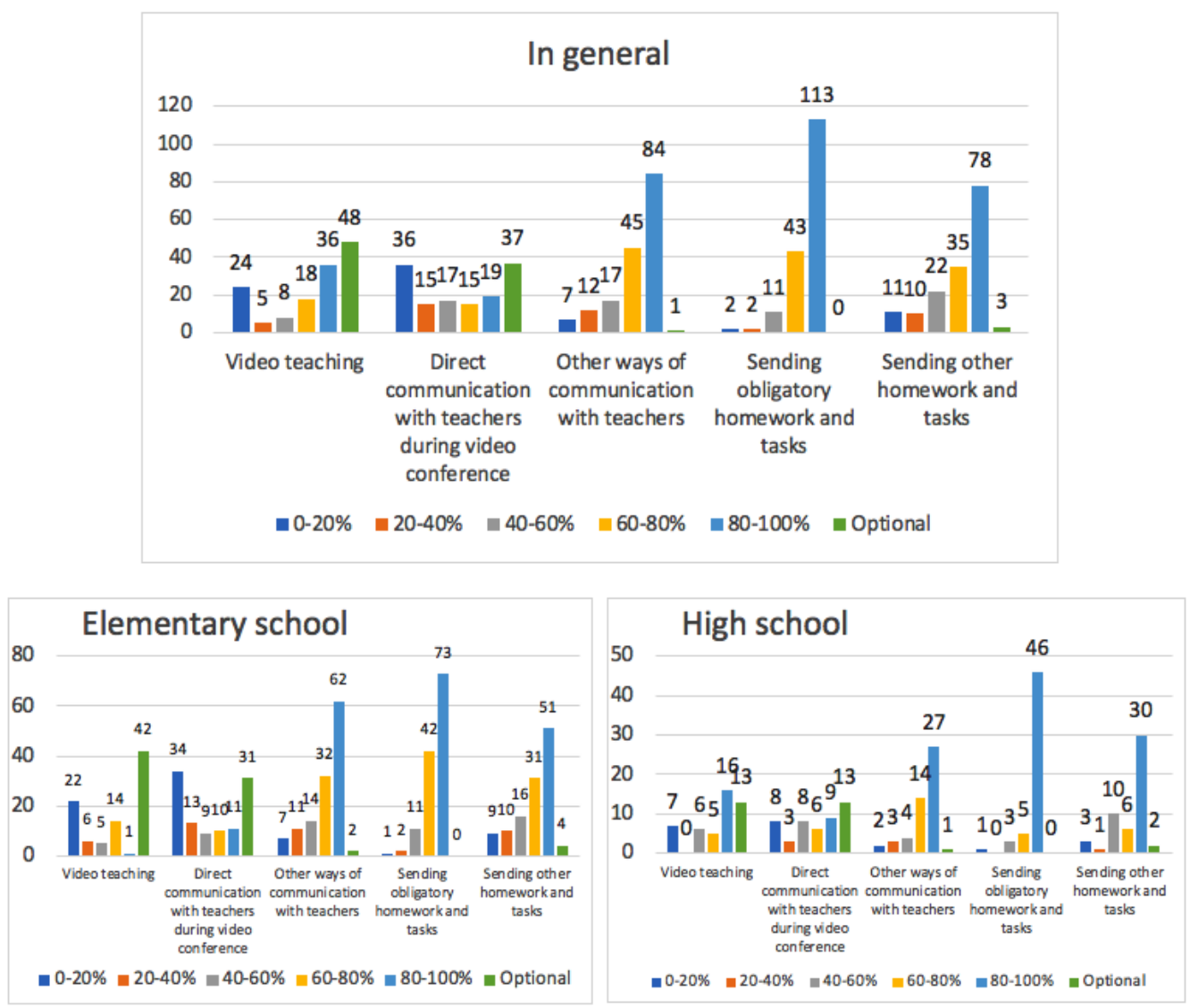

Note. $\mathrm{N}_{\text {elementary }}=128, \mathrm{~N}_{\text {high }}=57$ (7 teachers work in elementary and high school). Reflects the number of participants answering the question in certain way.

- $\quad$ RQ2: Which physics topics were taught and how extensively were they taught?

Figure 5 shows which physics topics were taught and how extensively were they taught during the Covid-19 lockdown. The data are given separately for elementary and high school. All of the curricular topics for elementary 
school are shown, and about 50\% of the teachers believe that their teaching of the topics was similar in detail to that of regular classes. About $10 \%$ believe that their teaching was even more detailed, and the rest believe that their teaching of these topics was superficial. In Figure 5, for elementary school, the "not covered" column is high for three topics - motion, internal energy and light indicating that those topics were quite frequently not taught. For motion, the explanation could be that the teachers had already covered the topic in the first semester (due to the curriculum). A possible explanation in the case of internal energy and light is that the teachers devoted more time to topics covering waves and energy, and so did not have time to cover one or two other topics. Even under regular conditions, many teachers do not teach about light and even internal energy; due to the overcrowded curriculum, teachers tend to focus on the subjects they think are more important.

For high school, the situation is somewhat different. Two topics were mostly not included ("not covered" columns). It is expected that even in regular classes, many teachers do not teach the topic of the special theory of relativity. However, this is not the case for fluids: it is the last topic in the third grade, so last year teachers obviously did not have time for it, possibly because they were focusing on the other topics that were more important to them. Moreover, these answers were expected for topics that are sometimes grouped under the common name Modern Physics (nuclear and quantum physics), either because there are no proper experiments that teachers can do in schools with students under regular conditions, or because the topics are covered very superficially under normal circumstances as well. In addition, this is the last topic in the fourth grade, which means that the same explanation as fluids could apply. 


\section{Figure 5}

Physics topics taught during the pandemic and the level of detail for elementary and high school
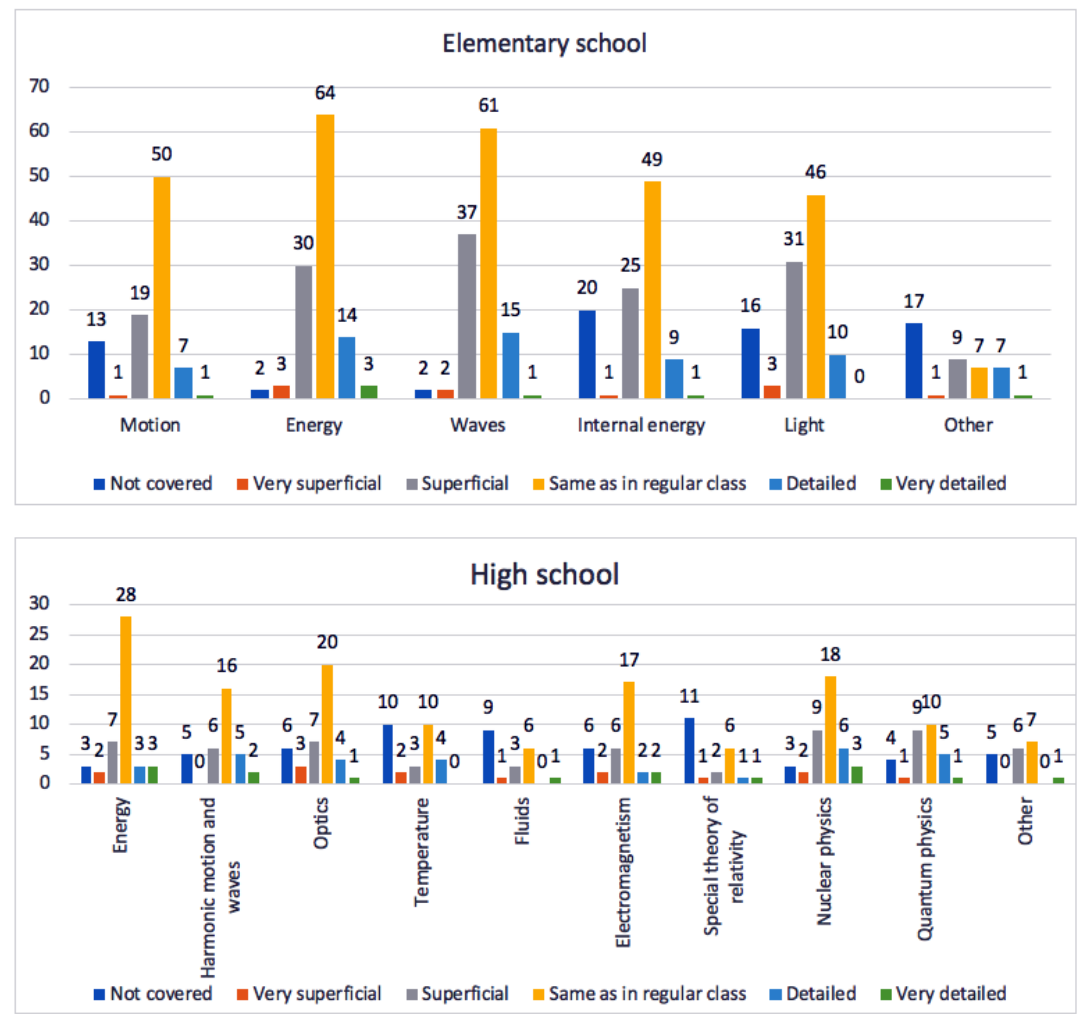

Note. $\mathrm{N}_{\text {elementary }}=128, \mathrm{~N}_{\text {high }}=57$ (7 teachers work in elementary and high school).

Reflects the number of participants answering the question in a certain way.

- $\quad$ RQ3: How was experimental work carried out during remote physics lessons?

Since experimental work - both demonstrations and laboratory exercises - was very much affected by remote teaching, a comparison was needed. The teachers were therefore asked to rate the equipment of the school in order to establish the context of the experimental situation in the schools before the lockdown. Since the teachers were from very different schools, the results ranged from "not equipped" to "very well equipped" (Table 4). A large number of the 
teachers are very satisfied with the experimental equipment in their schools.

\section{Table 4}

Assessment of the school equipment for physics lessons by the surveyed physics teachers

\begin{tabular}{lcccc}
\hline & \multicolumn{2}{c}{ Elementary school } & \multicolumn{2}{c}{ High school } \\
\cline { 2 - 5 } & $n$ & $\%$ & $n$ & $\%$ \\
\hline Not equipped & 4 & 3.13 & 4 & 7.02 \\
Poorly equipped & 18 & 14.06 & 13 & 22.81 \\
Equipped & 59 & 46.09 & 23 & 40.35 \\
Well equipped & 41 & 32.03 & 14 & 24.56 \\
Very well equipped & 6 & 4.69 & 2 & 3.51 \\
\hline
\end{tabular}

Note. $\mathrm{N}_{\text {elementary }}=128, \mathrm{~N}_{\text {high }}=57$ (7 teachers work in elementary and high school).

Figure 5 shows all of the regularly scheduled topics for the lockdown period. The yellow column is the most dominant: it is taught in as much detail as in regular classes. What does this mean? As a science subject in the school curriculum, physics is made up of three equally important parts: theory, problem solving and experiments. The prevailing opinion is that physics teaching during the Covid-19 lockdown was conducted in the same manner as when the teacher is in the classroom with the students. This means that physics concepts are introduced as interactively as they are in the regular classroom, that experiments are conducted in the same proportion as they are in the classroom, and that these experiments are not just demonstrative or shown as a picture in a book, for instance (i.e., the students are the ones conducting the experiments) (Cairns, 2019).

Figure 6 shows the results of how often teachers/students conducted experiments before and during lockdown. There is an obvious shift from "every hour" to "not at all". This is very surprising because it is highly inconsistent with the answers to the previous question about the topics taught and how extensively they were taught. Almost $63 \%$ of the teachers did not conduct any experiments at all, and $25 \%$ of them did so very rarely (perhaps once in the entire period of lockdown). When the data is split between the elementary and high school teachers, it turns out that the situation was slightly better in elementary schools. This may be because the experiments are easier in elementary school and the students can do them independently during regular classes. Examining the data for high school more closely, we see that most teachers do experiments about once every four lessons or even less under regular conditions. However, 
if we look at the last two parts of the Figure 6, we see that under regular conditions, "very rarely" and "not at all" are not present in the data for elementary schools, but are present in the data for high schools. The problem of the absence of experiments in physics classes has already been demonstrated (Marušić \& Sliško, 2012; Smith et al., 2020). It is also clear from these figures that elementary physics teachers put more effort into conducting experiments during lessons (under both regular and Covid-19 conditions) and that they have done so. However, the question as to why this is the case when the teachers state that they are very satisfied with the school experimental set-up remains to be investigated. Nonetheless, there are statistically significant differences $(t=15.97$, $\mathrm{p}<.01)$ in the quantity of experiments in physics lessons before and during the pandemic.

\section{Figure 6}

Frequency of conducting experiments before and during lockdown, in general and separately for elementary and high school
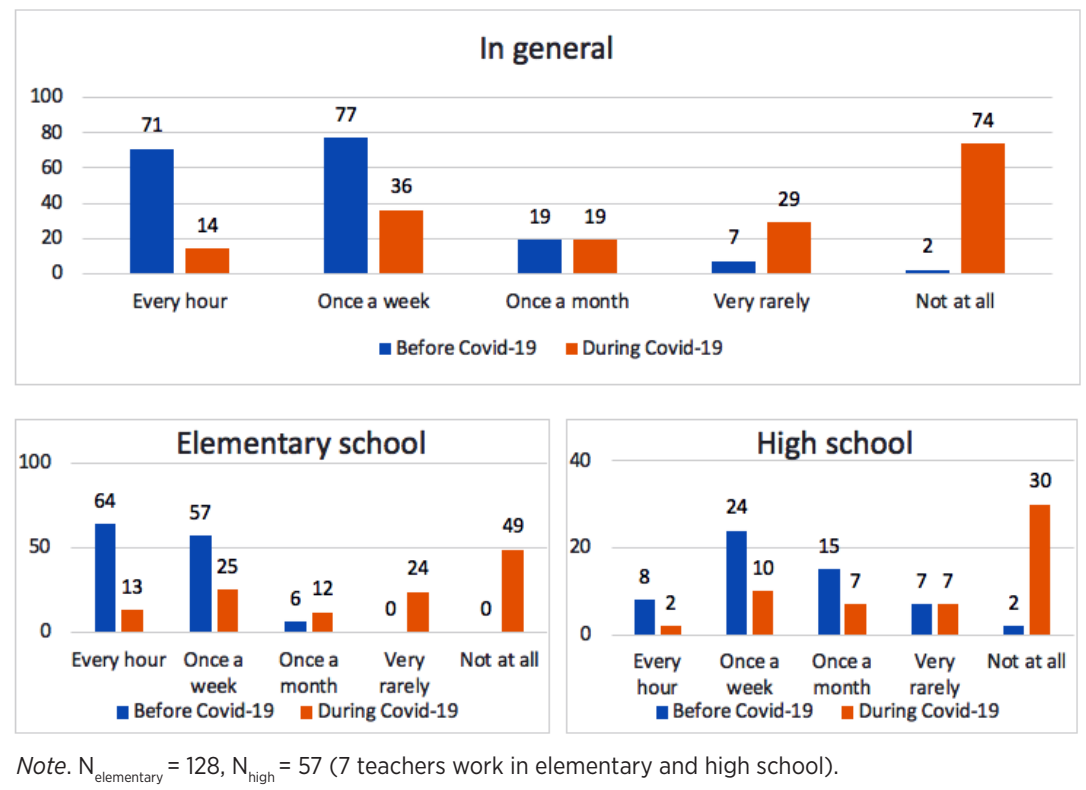

Reflects the number of participants answering the question in a certain way.

In addition to the frequency of conducting experiments, it is also interesting to see what types of experiments the teachers conduct (if any). The data in Figure 7 show the types of experiments conducted in elementary and high 
school, both before and during the Covid-19 lockdown. The shift to demonstration experiments is evident, as lab work and hands-on experiments move from "most often" and "often" to "never". Demonstration experiments consistently shift from "never" or "rarely" to "often" and "most often" for video, picture or other ICT. These results were expected due to the sudden change to remote conditions. Moreover, for the type of experiments referred to as home experiments, it is noted that they were conducted "less frequently" during the Covid-19 situation. This was expected in part due to the many additional student obligations during this time, or to the increased teacher obligations and the lack of time to prepare these experiments.

\section{Figure 7}

Types of experiments performed before and during the Covid-19 lockdown in general, divided for elementary and high school
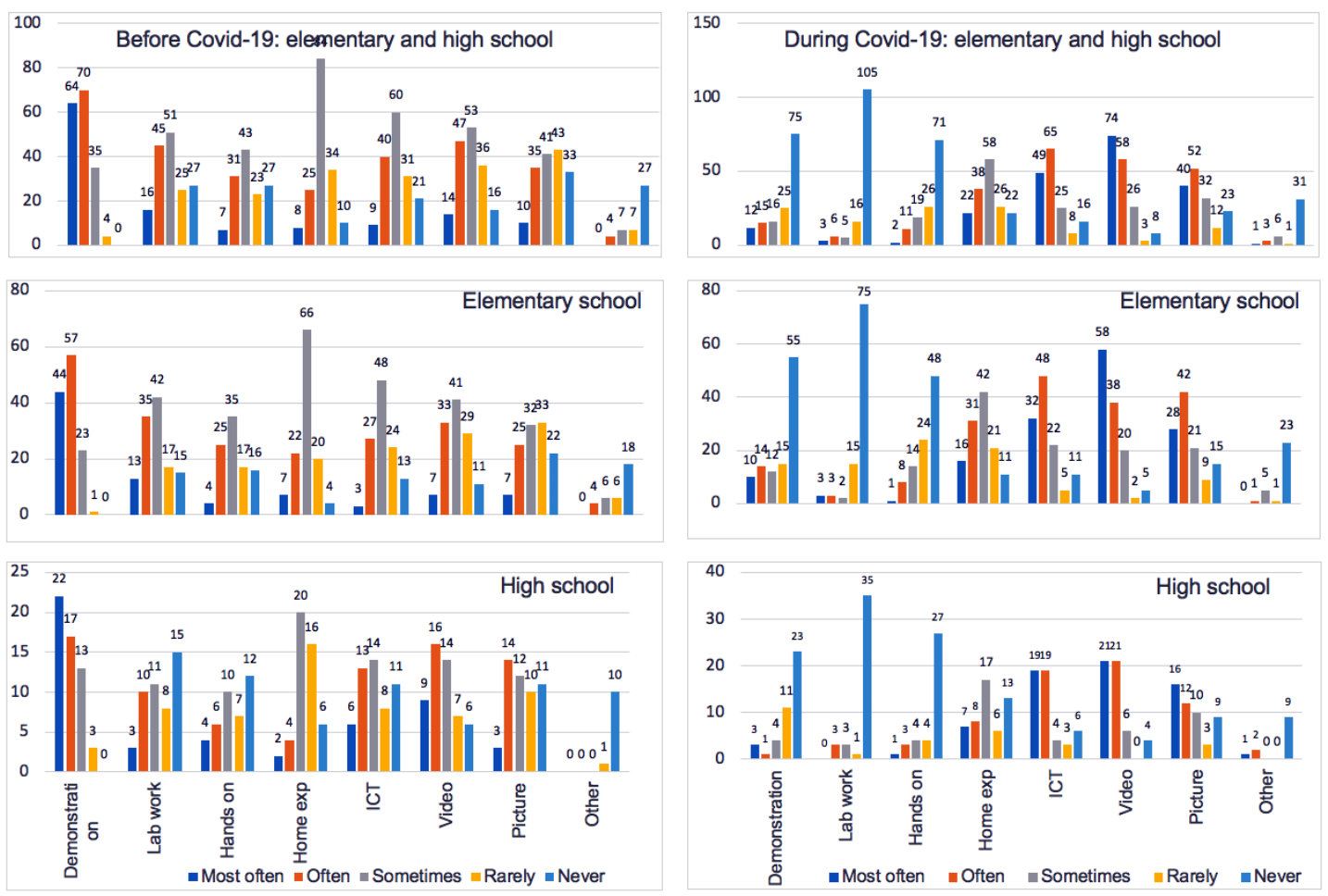

Note. $\mathrm{N}_{\text {elementary }}=128, \mathrm{~N}_{\text {high }}=57$ (7 teachers work in elementary and high school). 
- $\quad$ RQ5: How did physics teachers perceive the workload during the remote teaching period?

Figure 8 presents how teachers perceived the workload during the Covid-19 situation. In every aspect of the teachers' work, they reported that the workload increased (60\% of the respondents or more). This could be another reason for not conducting experiments during the Covid-19 period.

\section{Figure 8}

Number of answers regarding use of time for specific tasks compared to before the Covid-19 era

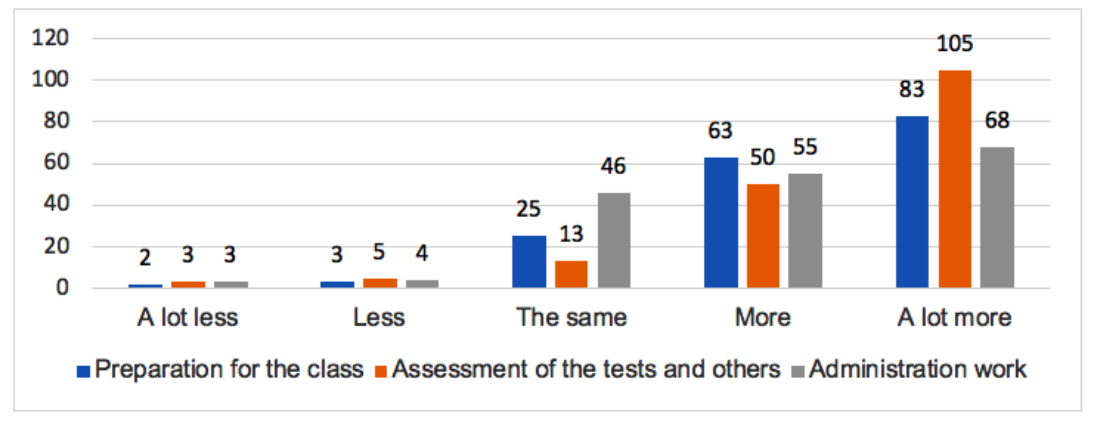

Why does this congestion occur? If we recall the beginning of the spread of Covid-19 in Europe and Croatia, it was very sudden, there was no preparation, and the transition to online teaching was announced only a few days before it actually happened. During this short period of time, teachers were left to transfer their materials to an online form, to conduct tests and devise assessment tools, to find appropriate ICT tools and applications, and to learn to use these tools (themselves and their students). The online materials from the MSES and "School on the Third Channel" (especially for elementary students) were a help, as were the prescribed lesson plans for all teachers, but all of this was framed in general, and, as stated above, not all teachers were on the same topic at the same time due to the first semester and the strike. Everything had to be customised for each class, each school and each teacher. This was in fact a major problem. Due to the hourly rate prescribed by the Ministry, one teacher can teach up to five grades, whether the same or different (Ministry of Science, Education and Sport, 2014). In addition to all of this, the school system in Croatia is going through a reform called "School for Life" (affecting elementary school more than high school), according to which teachers are using much more ICT to prepare more interactive and better designed school lessons. Although some of the teachers surveyed reported being familiar with the advantages and 
disadvantages of online tools and applications and had used them for some time, they had never used them to teach everything and every lesson in this way.

This could be an appropriate moment to raise awareness about the future of ICT in the teaching process. Teachers should receive quality training to increase ICT competences, both for carrying out experimental work through ICT and for better and greater digitisation of teaching materials.

- $\quad$ RQ4: How did Covid-19 affect assessment of students' physics knowledge?

The teachers assessed student knowledge in all classes, both formatively and summatively (Figure 9) (Black, 1993). Under regular conditions, all teachers know how and when to assess their students (by setting up a yearly plan at the beginning of the school year), but when the situation changed to distance learning, they had to find a new way to assess student knowledge, both formatively and summatively. Figure 9 presents the results of how teachers assess student knowledge and the grades students achieved, averaged per student over one month, both together and divided by school level.

Almost every teacher, from both elementary and high school, gave from one to three grades per student in a month. It could be said that this was very similar to regular conditions, but on examining the assessment evaluation more closely it is clear that the time needed was much longer than in regular classes. The teachers claim that the preparation of quizzes, tests and online homework is very time consuming: they had to prepare more questions and tasks to avoid cheating, they had to choose the proper application that the students know how to use during tests/quizzes, and at the end they had to correct all of the tests obtained through online applications.

Another very important issue is the stability of internet connection for all of the students taking the tests/quizzes. What about questions during direct teaching? How should teachers assess a particular student activity? How should they perform an interactive class in front of the screen, when sometimes watching blank screens instead of students' faces? The teachers reported that students were not allowed to turn on cameras (according to MSES recommendations).

The following are examples of the teachers' statements:

"I taught physics using the Teams application. The disadvantage is that we were not allowed to use cameras according to the Minister's instructions. The advantage is that students were able to solve unclear questions without fear or shame."

"I have used video lessons of the School for Life, done audio presentations, used Eduvision, used MForms to check knowledge, made video instructions on how to use digital tools in class (children are quite digitally 
ignorant; it is a problem is to send mail, to activate an attached link, to use One note), and used Edutorium."

"Problems with connection, materials not delivered, frequent interruptions on both sides, overload, and hours and hours of work on the computer ..." "We were told not to insist on direct (simultaneous) teaching."

"The problem is that households are poorly equipped with technology and cannot participate in classes!"

It was reported that checking student attendance was difficult. Each student had to turn off the microphone while the teacher was speaking; the microphone was only on when it was the respective student's turn to talk or answer. Due to the internet connection, this can be a very long process, even for only one or two questions per lecture, so how can interactive teaching can be performed in these circumstances? And how can grades be given for the activity during online classes? From all of the data, it is evident that the teachers put a lot of effort into this aspect of teaching physics.

\section{Figure 9}

Assessment of students' physics knowledge performed by the surveyed physics teachers

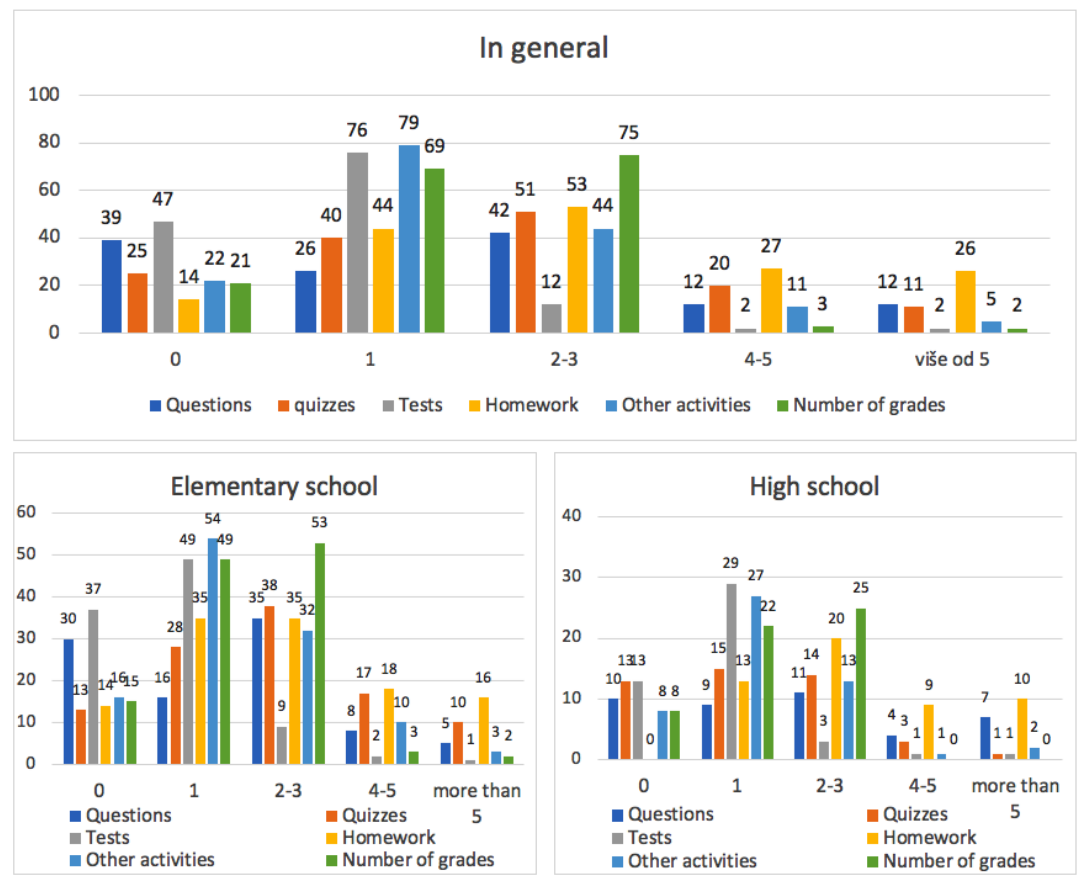

Note: $\mathrm{N}_{\text {elementary }}=128, \mathrm{~N}_{\text {high }}=57$ (7 teachers work in elementary and high school). 
Reflects the number of participants answering the question in a certain way.

- $\quad$ RQ6: How was communication with students carried out during and alongside physics lessons?

During the time of online teaching, communication with students was crucial for any kind of questions and help. The most common help students asked for was with numerical tasks, homework and experiments, or other tasks that students had to do themselves. This was expected, as it is similar in regular classes, but in online teaching the need for help increased. Teachers therefore put many extra hours into communication. Below are some quotes from the surveyed teachers about what students asked and what kind of help they were looking for.

"Additional instructions for tasks, additional explanation of procedures for solving tasks, additional explanation for research work."

"Questions on material worked on, instructions on experiments, instructions on individual work."

"Most problematic was using the material in conceptual tasks and problem tasks, as well as in regular classes."

"They ask for help with everything that would not occur in the regular classroom."

Figure 10 shows that among the apps for any kind of communication during online teaching during this first days of Covid-19 lockdown, TEAMS, email, Yammer, Viber and Moodle predominate. We believe that this choice was made because of the familiarity of the apps for teachers and students during regular times, so nothing new (or almost nothing) needed to be learned.

\section{Figure 10}

Ways of communication between physics teachers and their students, as listed by the surveyed physics teachers

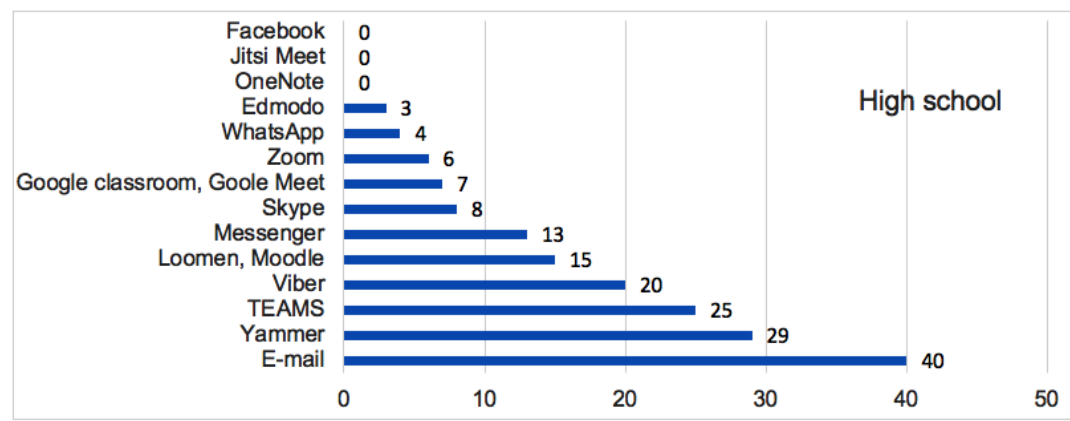

Note. $\mathrm{N}_{\text {elementary }}=128, \mathrm{~N}_{\text {high }}=57$ (7 teachers work in elementary and high school). 
Reflects the number of participants answering the question in a certain way.

Over time, teachers saw other opportunities in other applications, and students had time to learn how to use them. One positive outcome in this regard is that $80 \%$ of the teachers surveyed said that they would use some of the applications used during the Covid-19 conditions during regular teaching conditions as well (video lecturers and experiments, quizzes and online tests for repetition, app for communication, like MS Teams, Zoom, etc.).

Finally, it can be noted that in addition to the teaching hours regulated by the timetable (elementary school: $21 \pm 4$, high school: $21 \pm 2$ ), teachers had an additional $22 \pm 6$ contact hours with students per week in high school, and $15 \pm 9$ hours per week in elementary school. The standard deviation is quite large because not all of the teachers had the same number of classes (elementary school: $4 \pm 3$, high school: $6 \pm 3$ ) where there is a large discrepancy, nor did they have the same number of students in classes (elementary school: 19 \pm 1 , high school: $22 \pm 3)$.

\section{Conclusion}

This paper presents a Croatian study of physics lessons during the Covid-19 pandemic. The results of the study show the following. Despite all of the problems in organising distance learning, Croatian teachers adhered to the prescribed schedule that applies in regular classes $(76 \%)$, but were much more flexible in requiring attendance in direct classes during the lockdown (almost half did not require students to be present in direct online teaching). Moreover, the prevailing opinion is that topics were taught in as much detail during lockdown as in regular classes. However, this is contrasted by an apparent shift from the regular conducting of the experimental part of lessons to conducting experiments "very rarely" or "not at all" during the teaching process. A more detailed investigation showed that teachers managed to replace the experimental part of physics lessons during online teaching, covering it with video materials, simulations and a positively larger volume of home experiments. The next contribution of the research relates to the assessment of student knowledge during online teaching. Regardless of all the problems and time requirements, teachers were very active and assessed student activities with a large number of grades (1-3 per month), which is comparable to the numbers in regular classes. All in all, teachers felt quite overloaded with their work commitments, and more working hours were spent on preparation of remote online classes. In the end, 
however, $80 \%$ of the teachers surveyed believe that even under regular conditions they will use some of the teaching methods they had to use during the pandemic Covid-19 for online teaching in the future.

During the open data analysis, it became clear that although this period of teaching and life in general was difficult and unfamiliar, the active generation of teachers was flexible, adaptable and open to new ways of teaching. They struggled and fought to give their students the maximum and allow them to construct the required knowledge.

Physics teachers have already adopted some online teaching, which is certainly a positive side of the Covid-19 pandemic, and many of them will continue to use such teaching in the future when they return to regular teaching. If online teaching and digitalisation of the teaching process increases in the future and the traditional way of teaching slowly fades away, then this lockdown and the online teaching that is still ongoing (in some form) can certainly serve as a model for how to change and adapt teaching from one form to another in response to circumstances. In accordance with the research results, it can be concluded that it is necessary to increase teacher motivation for lifelong learning and increase their awareness of the importance of the experimental and research process in physics teaching. This should be done by increasing competencies in these two fields, as well as in modern teaching methods and the application of ICT in teaching, which is an indispensable part of the teaching process of the present, and will be especially important in the future. The school's investment in mobile experimental equipment and the use of platforms for virtual and remote experimental work should be the focal point. However, it should be emphasised that the future of the teaching process lies in its digitalisation. In addition, leaving students with an independent research process, which proved to be excellent during the lockdown, should certainly be carried out in both regular and lockdown conditions. For this purpose, the teacher must be well trained and confident enough to become a good mentor and leader of student research and the entire learning process. When a similar situation occurs in the future, more support should therefore be given to teachers during the transition, which should be greatly facilitated by the above suggestions.

During hybrid teaching, it is planned to continue the research to gain a more detailed insight into the use of methods and ICT from the lockdown era and how the transition from face-to-face to online teaching looks now compared to the beginning.

The limitation of the study partly lies in the anonymity of the teachers and the impossibility of additionally interviewing those who are very good at online teaching and those who are just the opposite. Despite this limitation, 
answering the questionnaire openly and honestly was more important at this point. Another limitation is the generalisation of the results, which are limited to the sample size of physics teachers.

\section{Acknowledgment}

We would like to thank all of the teachers who participated in this research despite their busy schedules with students and professional/private commitments during the Covid-19 lockdown.

\section{References}

Azlan, C. A., Hsiu Ding Wong, J., Kuo Tan, L., Shahrun Nizam A. D. Huri, M., Min Ung, N., Pallath, V., Phoay Lay Tan, C., Hong Yeong, C., \& Ng, K. H. (2020). Teaching and learning of postgraduate medical physics using Internet-based e-learning during the COVID-19 pandemic - A case study from Malaysia. Physica Medica, 80, 10-16.

Bao, W. (2020). COVID-19 and online teaching in higher education: A case study of Peking University. Human Behavior and Emerging Technologies, 2(2), 113-115.

Black, P. J. (1993). Formative and summative assessment by teachers. Studies in Science Education, 21(1), 49-97.

Bornstein, M. H., Jager, J., \& Putnick, D. L. (2013). Sampling in developmental science: situations, shortcomings, solutions, and standards. Developmental Review, 33(4), 357-37o.

Cairns, D. (2019). Investigating the relationship between instructional practices and science achievement in an inquiry-based learning environment. International Journal of Science Education, 41(15), 2113-2135.

Constitutional Court of the Republic of Croatia. (n.d.). Zakon o odgoju i obrazovanju u osnovnoj $i$ srednjoj školi [Primary and secondary school education act]. https://zakon.hr/z/317/Zakon-o-odgojui-obrazovanju-u-osnovnoj-i-srednjoj-\%C5\%A1koli

Eurydice. (2021). Educational system in Croatia. https://eacea.ec.europa.eu/national-policies/ eurydice/content/croatia_en

Guo, S. (2020). Synchronous versus asynchronous online teaching of physics during the COVID-19 pandemic. Physics Education, 55(6), 60-69.

Haagen-Schützenhöfer, C., \& Joham, B. (2018). Professionalising physics teachers in doing experimental work. Center for Educational Policy Studies Journal, 8(1), 9-34.

Hodson, D. (2014). Learning science, learning about science, doing science: Different goals demand different learning methods. International Journal of Science Education, 36(15), 2534-2553.

Kireš, M. (2018). Let's repair the broken Galileo thermometer. Center for Educational Policy Studies Journal, 8(1), 77-95.

Klein, P., Ivanjek, L., Dahlkemper, M. N., Jeličić, K., Geyer, M.-A., Küchemann, S., \& Sušac, A. (2021). 
Studying physics during the COVID-19 pandemic: Student assessments of learning achievement, perceived effectiveness of online recitations, and online laboratories. Physical Review Physics Education Research, 17(1), 010117-1-010117-11.

Kluge, A. (2014). Combining laboratory experiments with digital tools to do scientific inquiry. International Journal of Science Education, 36(13), 2157-2179.

Marušić, M., \& Sliško, J. (2012). Influence of three different methods of teaching physics on the gain in students' development of reasoning. International Journal of Science Education, 34(2), 301-326. Milas, G. (2005). Istraživačke metode u psihologiji i drugim društvenim znanostima [Research methods in psychology and other social sciences]. Naklada Slap.

Ministry of Science and Education. (2020, April). Upute za vrednovanje i ocjenjivanje tijekom nastave na daljinu [Instructions for evaluation and assessment during distance learning]. https://mzo.gov.hr/ UserDocsImages/dokumenti/Obrazovanje/Upute-za-vrednovanje/Upute\%20za\%2ovrednovanje\%2O i\%2oocjenjivanje\%2otijekom\%2onastave\%2ona\%2odaljinu.pdf

Ministry of Science and Education. (2020, 11 March). Smjernice osnovnim i srednjim školama vezano za organizaciju nastave na daljinu uz pomoć informacijsko - komunikacijske tehnologije [Guidelines for primary and secondary schools related to the organisation of distance learning with the help of ICT]. https://mzo.gov.hr/UserDocsImages/dokumenti/Vijesti/2020/Smjernice\%20osnovnim\%2oi\%2O srednjim\%2oskolama\%2ovezano\%2ouz\%2oorganizaciju\%2onastave\%2ona\%2odaljinu.pdf Ministry of Science and Education. (2020, 13 March). Uputa svim osnovnim i srednjim školama vezano $\mathrm{uz}$ nastavak organizacije nastave na daljinu [Instructions to all primary and secondary schools regarding the continuation of the organisation of distance learning]. https://mzo.gov.hr/ vijesti/uputa-svim-osnovnim-i-srednjim-skolama-vezano-uz-nastavak-organizacije-nastave-na-dalji nu/3592?fbclid=IwAR1DFxoVdasTDMe_s3uOtz_fgIeZ_RdPpbE_uMXgr3Sowb3oholYh5T5syY Ministry of Science and Education. (2020, 19 March). Odluka o obustavi izvođenja nastave i uspostavi nastave na daljinu [Decision on the suspension of teaching and the establishment of distance learning]. https://skolazazivot.hr/odluka-o-obustavi-izvodenja-nastave-i-uspostavi-nastave-na-daljinu/ Ministry of Science and Education. (2021). List of elementary and middle schools. https://mzo.gov.hr/ ustanove/103

Ministry of Science, Education and Sport. (2006). Odluka o nastavnom planu i programu za osnovnu školu [Decision about the curriculum for primary school]. https://narodne-novine.nn.hr/clanci/ sluzbeni/2006_09_102_2319.html

Ministry of Science, Education and Sport. (2014). Pravilnik o tjednim radnim obvezama učitelja i stručnih suradnika u osnovnoj školi [Ordinance on weekly work obligations of teachers and professional associates in elementary school]. https://narodne-novine.nn.hr/clanci/ sluzbeni/2014_03_34_613.html

Ministry of Science, Education and Sport. (2019). Odluka o donošenju kurikuluma za nastavni predmet fizike za osnovne škole i gimnazije u Republici Hrvatskoj [Decision on the adoption of the curriculum for the subject Physics in elementary and high school in Croatia]. https://narodnenovine.nn.hr/clanci/sluzbeni/2019_01_10_210.html 
Repnik, R., \& Ambrožič, M. (2018). Practical school experiments with the centre of mass of bodies. Center for Educational Policy Studies Journal, 8(1), 97-116.

Schröder-Turk, G. E., \& Kane D. M. (2020). How will COVID-19 change how we teach physics, post pandemic? Physical and Engineering Sciences in Medicine, 43(3), 731-733.

Sindiani, A. M., Obeidat, N., Alshdaifat, E., Elsalem, L., Alwani, M. M., Rawashdeh, H., Fares, A.S., Alalawne, T., \& Tawalbe, L. (2020). Distance education during the COVID-19 outbreak: A crosssectional study among medical students in North of Jordan. Annals of Medicine and Surgery, 59, 186-194.

Smith, E. M., Stein, M. M., Walsh, C., \& Holmes, N. G. (2020). Direct measurement of the impact of teaching experimentation in physics labs. Physical Review, X, 10(1), 011029-1-011029-21.

Snětinová, M., Kácovský, P., \& Machalická, J. (2018). Hands-on experiments in the interactive physics laboratory: Students' intrinsic motivation and understanding. Center for Educational Policy Studies Journal, 8(1), 55-75.

Sullivan, S., Gnesdilow, D., Puntambekar, S., \& Kim, J.-S. (2017). Middle school students' learning of mechanics concepts through engagement in different sequences of physical and virtual experiments. International Journal of Science Education, 39(12), 1573-1600.

Tinio, V. L., Programme, U. A.-P. D. I., \& Force, e-ASEAN T. (2003). ICT in education /.

Digitallibrary.un.org. https://digitallibrary.un.org/record/524544.

Tinio V.L., ICT in Education (2011). Bused by the Asia-Pacific Development Information Programme (APDIP) 2007, 6. http://www.apdip.net.

Union. (2020, June 24). The likely impact of COVID-19 on education: Reflections based on the existing literature and recent international datasets. Op.europa.eu. https://op.europa.eu/en/publicationdetail/-/publication/b48d5of6-b753-11ea-bb7a-o1aa75ed71a1/language-en Walan, S., \& Chang Rundgren, S. (2014). Investigating preschool and primary school teachers' selfefficacy and needs in teaching science: A pilot study. Center for Educational Policy Studies Journal, $4(1), 51-67$. 


\section{Biographical note}

IVANA ŠTIBI, doctoral student at University of Ljubljana, Faculty of Mathematics and Physics, Slovenia, and working as a lecturer at the University Josip Juraj Strossmayer, Department of Physics in Osijek, Croatia. The current focus of the research is on the impact of online teaching in pre-university and university level of education and the development of a methodical and didactic materials in physics (focused on the experimental part of teaching), suitable for online and hybrid forms of physics teaching within the entire educational vertical.

MoJCA ČEPIČ, PhD, Full Professor for general physics and physics education, is an expert in the methodology of teaching physics through inquiry-based learning. She has been leading several research projects on the introduction of new fundamental physics results into all levels of education and its application for the identification of gifted students. The approach is focused on students who come from underprivileged circumstances and are less skilled in regular school tasks. She has been the Head of the Department of Physics and Technology for several years and currently leads the Institute for Science and Arts at the Faculty of Education, University of Ljubljana.

Jerneja Pavlin, PhD, is an Assistant Professor of Physics Education at University of Ljubljana, Faculty of Education, Slovenia. Her research focuses on the investigation of different approaches to physics and science teaching (e.g. outdoor teaching and learning, using $3 \mathrm{D}$ sub-microscopic representations, didactic games, learning by inquiry, peer instruction etc.), aspects of scientific literacy and the introduction of contemporary science into physics teaching. She is involved in several research projects in the field of science and physics education (e.g. NA-MA POTI, AR Physics made for students, Movement-dance stories in connection with science and social sciences in kindergarten and school, Connectedness with nature, the organization of early school-aged students' free time and digital technologies). 